\title{
Of Mice and Ice in the Late Pliocene of North America
}

\author{
CHARLES A. REPENNING ${ }^{1}$
}

(Received 19 June 1989; accepted in revised form 22 February 1990)

ABSTRACT. Between 2.5 to 1.8 million years ago changes in arctic climate and in meadow mouse dispersal routes correlate with part of the history of uplift and glacial erosion of the Chugach and Saint Elias mountains in Alaska and adjacent Canada. Earlier meadow mice dispersing from Asia to central North America followed a southward coastal route between these mountains and the Pacific Ocean, appearing first in the United States Pacific Northwest. Two and a half million years ago, accelerated uplift of the Chugach and Saint Elias mountains milked Pacific westerly winds, enlarging the ice fields in these mountains so that they then flowed to the sea. This blocked the coastal dispersal for 600000 years, when no new immigrant meadow mice appeared in the conterminous United States. The uplift also restrained westerly winds that crossed Canada, permitting moister air from the subtropical Atlantic and from an unfrozen Arctic Ocean to produce significant continental glaciation, centered in eastern Canada.

By 2.0 million years ago, glacial erosion had lowered these mountains again, letting relatively dry Pacific westerlies extend across Canada, reducing the encroachment of moist Atlantic and arctic air, and ending continental glaciation to the east. The simultaneous reduction of glacial activity in the cordillera allowed meadow mice to renew southward dispersal. Additionally, the lowered mountains remained a rain shadow, causing grassland in the Great Plains of Canada. Thus a new dispersal route to the United States was opened for grazing meadow mice and for the first time their earliest records were in the Great Plains.

Loss of the continental ice sheet and an unfrozen Arctic Ocean facilitated the northward spread of warm and moist air from the North Atlantic subtropical high; it flowed northward up the eastern front of the Rocky Mountains in the United States and, mingling with the dry westerlies, northeastward across Canada to northernmost Greenland, where trees then grew. About 1.8 million years ago the Great Plains of the United States were subtropical savannah and remained so until the beginning of the Ice Age 850000 years ago.

Key words: Arctic, Pliocene-Pleistocene, glacial climate, microtine rodent dispersal

RÉSUMÉ. Les modifications du climat arctique et des routes de migration du campagnol des champs depuis l'Asie jusque dans le centre de l'Amérique du Nord il y a de 2,5 à 1,8 millions d'années confirment en partie l'histoire du soulèvement et de l'érosion glaciaire des monts Chugach et St. Elias en Alaska et dans la région voisine du Canada. Les campagnols des champs qui ont migré plus tôt ont tous emprunté dans leur migration vers le sud une route côtière passant entre ces montagnes et l'océan Pacifique, se manifestant d'abord dans le Pacifique nord-ouest des États-Unis. Il y a 2,5 millions d'années, le soulèvement accéléré des monts Chugach et St. Elias, en s'opposant aux vents d'ouest du Pacifique, a favorisé le développement dans ces montagnes des champs de glace qui se sont ensuite écoulé vers la mer. Ainsi, la migration côtière a été bloquée et, pendant 600000 ans, aucun nouveau campagnol des champs n’a pu immigrer dans les états américains limitrophes. Ce soulevement a aussi limite les vents d'ouest qui balayaient le Canada, permettant à l'air plus humide de l'Atlantique subtropical et d'un océan Arctique sans glace de produire une glaciation continentale importante, centrée dans l'est du Canada.

Il y a 2,0 millions d'années, l'érosion glaciaire avait rabaissé la hauteur de ces montagnes, laissant les vents d'ouest du Pacifique relativement secs balayer le Canada et mettre fin à la glaciation continentale à l'est. La diminution concourante de l'activité glaciaire dans la cordillère a permis au campagnol des champs de reprendre sa migration vers le sud. En outre, les montagnes désormais plus basses ont continué d'abriter la région sous le vent contre la pluie, permettant la création de prairies dans les grandes plaines du Canada. Le campagnol des champs a par la suite établi une nouvelle route de migration vers les États-Unis et, pour la première fois, sa présence a été relevée dans les grandes plaines.

La disparition de la calotte glaciaire continentale et l'absence de glace dans l'Arctique ont facilité le mouvement vers le nord de l'air chaud et humide depuis la crête subtropicale de l'Atlantique nord; cet air s'est déplacé vers le nord jusqu'au front oriental des Rocheuses aux ÉtatsUnis et vers le nord-est à travers le Canada jusqu'aux confins septentrionaux du Groenland où il paoussait alors des arbres. Il y a environ 1,8 million d'années, les grandes plaines des États-Unis étaient une savanne subtropicale qui est demeurée ainsi jusqu'au début de l'époque glaciaire il y a 850000 ans.

Mots clés: Arctique, Pliocène-Pléistocène, climat glaciaire, migration des microtinés

РЕФЕРАТ. Происходнвшие 2,5 - 1,8 миллиона лет назад изменения климата Арктики и путей, по которым полевки расселялись из Азии в центральные районы Северной Америки, соответствуют определенному периоду в истории поднятия и ледниковой эрозии тор чугач и Св. Ильи на Аляске и в соседних районах Канады. До этого периода мигрирующие полевки продвигались на юг вдоль побережья между этими горами и Тихим океаном. засе-ляя в первую очередь северозападные тихоокеанские районы Соединенных Штатов. Два с половинои миллиона лет тому назад быстрое поднятие гор Чугач и Св. Ильи ослабило западные тихоокеанские ветры, что привело х росту ледников на склонах этих гор и сползанию этих ледников $\mathbf{K}$ океану. В результате этого миграция вдоль побережья стала невозможной, и в течение 600000 лет новые мигрирующне полевки не появлялись в прилегаю щихраћонах Соединенных Штатов. Поднятие гор также ограничило действие западных ветров на территории Канады, что оолегчило доступ на эту территорию более влажным ветрам из субтропических районов Атлантикн и $\infty$ стороны незамерзающего Северного Ледовитого океана. это привело $\mathrm{k}$ развитию значительного континентального обледенения с центром в Восточной Канаде.

Примерно две миллиона лет тому назад ледниховая зрозия вновь понизила эти горы, позволив относительно сухим тихоокеанским западным ветрам проникать до Атлантнческого океана и положив тем самым конец континентальному оледенению на востоке. одновременно снизился уровень активности ледников в горах западного побережья Северной Америки, и полевки смогли возобновить расселение в ожном направлении. Кроме того, понизившиеся горы продолжали создавать "дождевую тень", что привело к развитию травянистой растительности на Великих равнинах Канады. Это открыло полевкам новы П путь в Соединенные Штаты и позволило им впервые проникнуть на территорию Великих равнин.

Отсутствие льда на материке и в водах Северного Ледовитого океана облегчило распространение на север теплого и влажного воздуха нз субтропических раһ̆онов высокого давления Северной Атлантики. Этот воздух распространялся на север вдоль восточных склонов Скалистых гор в Соеднненных Штатах и на северо-восток через всю Канаду до северноЯ оконечности Гренландии, которая В то время была покрыта лесом. Около 1,8 миллионов лет тому назад Великие равнины Соединенных Штатов представляли собой субтропическую са-ванну, которая сохранялась там до наступления эпохи оледенения $\mathbf{8 5 0 0 0 0}$ лет тому назад.

Ключевые слова: Арктика, плиоцен-плейстоцен, ледниковый климат, расселение полевок

\footnotetext{
${ }^{1}$ United States Geological Survey, Mail Stop 919, Federal Center Box 25046, Denver, Colorado 80225, U.S.A.

(c)The Arctic Institute of North America
} 


\section{INTRODUCTION}

It has been established that variations in the Earth's orbital geometry correlate with climatic changes on the surface of the world. Some have inferred from this that climatic changes are primarily the result of orbital factors; yet most are willing to agree that world climate will change dramatically during the next 100 years because of changes in atmospheric gas proportions, a change difficult to attribute to orbital parameters. In addition to orbital eccentricities, many other factors have been considered as possible contributors to the climatic patterns as the world knows them today. In most cases, the logic of this consideration has been, simply, the temporal correlation of sets of events with climatic changes, as in the case of orbital parameters and oxygen isotope variations in oceanic cores.

By chain reaction, climatic changes are global in extent, and it appears that a coincidence of orbital cycles with orogenic cycles will ultimately be identified as the primary cause of the climatic changes, both atmospheric and oceanic. Other factors, such as atmospheric or oceanic composition, are significant but, possibly, secondary to these.

Orogenic factors other than those here discussed, such as the uplift of the Himalayas and the Tibetan Plateau (Ruddiman and Raymo, 1988), have also affected the climatic history of the Arctic Ocean region and the rest of the world. The presence of more than one cause of climatic change complicates the interpretation of climatic history as here inferred. The ultimate explanation of climatic change appears so complicated that, at present, one can only begin to tabulate possible factors. Varying rates of uplift and degradation of the northern part of the North American cordillera, here referred to as the Chugach and Saint Elias mountains of southern Alaska and adjacent Canada, are the topic of the present consideration and have been, since before the dawn of mankind, one of the more active orogenic regions of the world.

Suspicion of global climatic effects resulting from tectonic changes is certainly not new and probably long antedates the familiar example of the development of the North Atlantic Gulf Stream with the closure of the Central American Seaway (e.g., Repenning et al., 1975). This report presents a hypothesis regarding another orogenic contribution to the cause of climatic change that is based upon yet another temporal coincidence of a variety of evidence. Possibly it is unique only in that it is an early attempt to correlate the dispersal pattern of ecologically sensitive mice with the history of uplift of the northern part of the North American cordillera and with evidence of climatic change.

The "meadow mice" referred to in this hypothesis are a group of rodents related to hamsters but with high-crowned and complicated teeth designed for eating abrasive vegetation, primarily grass. They include lemmings, muskrats, and voles, but for simplicity only the genus Microtus is discussed at any length by its generic name. Microtus is a holarctic, temperate to arctic, grassland genus to which the term "meadow mouse" is usually applied. The meadow mice, in the allinclusive sense here employed (they are usually called the microtine or arvicolid rodents), did not exist before 9 million years ago, and they have developed their great variety since that time through very rapid evolution that is well documented (Repenning, 1987, for the U.S.A.; Fejfar and Heinrich, 1983, for Europe; and Repenning, 1984, for the Quaternary of the
Northern Hemisphere). This evolution is the basis for the most precise non-marine biochronology that exists for the Pliocene and the Pleistocene.

Most meadow mice evolved in the arctic regions of northern Asia and Beringia and then dispersed southward into temperate Europe and North America. Dispersal took place at particular times with the opening of climatically regulated environmental avenues. When climatic changes were frequent, dispersals were frequent; but on the average there has been a dispersal event about every 500000 years over the past 5 million years. These global dispersal events, in combination with documented evolutionary changes and provincial faunal differences between the dispersal events, provide a calibration of meadow mouse biochronology throughout the Northern Hemisphere; the biochronology so calibrated has a time resolution of about 100000 years under ideal conditions. Thus this time resolution is able to identify most climatic stages above the "noise" level.

During the late Pliocene there were major geographic modifications in this dispersal pattern, contemporaneous with major climatic changes. Inquiry into the climatic and topographic alterations that might have caused these changes in dispersal routes has led to the hypothesis that varying rates of uplift and degradation of the Chugach and Saint Elias mountains, along the Canada-Alaska Pacific Coast, were factors in both climatic and dispersal variations in North America during the last 2.5 million years.

The present hypothesis is built on the history of climatic change in the region of the Arctic Ocean and its borderland between 3.0 and 2.0 million years ago, ending with the conclusion of the first major Northern Hemisphere glaciation of the Cenozoic. This climatic history is outlined by Repenning et al. (1987) and Repenning and Brouwers (1987; in preparation) and is summarized below.

\section{CLIMATIC HISTORY OF THE ARCTIC OCEAN BORDERLAND}

Between 3 and 2 million years ago, the ecosystem of the Arctic Ocean Borderland went through a complete climatic cycle, which began with a forest bordering the Arctic Ocean that was composed of mixed conifers with much fewer numbers of deciduous hardwood trees. Over the first half million years of this cycle, the Arctic Ocean Borderland progressively changed to fully developed tundra and foresttundra with the first records of permafrost (Sher et al., 1979). The following half million years was marked by tundra and was accompanied by major Northern Hemisphere glaciation between 2.56 and 2.0 million years ago. This glaciation developed more than a million years earlier than those classically considered to represent the Ice Age (Nebraskan, Kansan, Illinoian, and Wisconsin), but it was present in both Scandinavia and North America; it deposited till as far south as Iowa in the United States (Easterbrook and Boellstorff, 1984). Glaciation in Eurasia appears to have been less extensive, but the Scandinavian ice sheet began developing about 2.56 million years ago, reached a peak between 2.2 and 2.0 million years ago, and collapsed 2.0 million years ago (Jansen $e t$ al., 1988). During this glaciation the Arctic Ocean became density-stratified and showed a marked increase in ice rafting (Herman et al., 1989).

Available evidence does not indicate that the Arctic Ocean was frozen between 2.56 and 2.0 million years ago. Fossil mammals and mollusks that cannot survive a frozen ocean 
are known from a 2.43 million-year-old coastal locality on the North Slope of Alaska (Repenning et al., 1987), indicating that the Arctic Ocean was not entirely frozen as briefly as one month out of the year, well after the first evidence of the growth of the Scandinavian ice sheet. Air temperatures in the Arctic Ocean Borderland were at times warmer than today during this glacial period, but colder at other times (Repenning et al., 1987). Winter freezing may have been possible near the end of this glaciation, when markedly colder climates are recorded in northeastern Siberia and western Alaska; Jansen et al. (1988) note relatively strong glacials of the Scandinavian ice sheet between 2.2 and 2.0 million years ago, and in northernmost Greenland, about $800 \mathrm{~km}$ from the North Pole, the oldest one-quarter of the Kap København Formation in northernmost Greenland contains dropstones, indicating iceberg activity (Funder et al., 1985).

The medial one-half of the Kap København Formation lacks these dropstones, contains a warmer marine fauna and high-energy coastal deposits, indicating strong wave action and, at least, no year-round ice cover. The youngest onequarter of this formation contains tree trunks nearly $0.6 \mathrm{~m}$ in diameter, a forest-tundra flora comparable to modern Labrador, a warm estuarine invertebrate fauna indicating warm subfrigid water, and a small mammalian fauna indicative of a 2.0 million year, or slightly younger, age (Funder et al., 1985; Repenning and Brouwers, in preparation; Bennike and Bocher, 1990-this issue).

Thus, glacial climate disappeared about 2.0 million years ago and mixed coniferous forests returned, extending to the northernmost shores of the Arctic Ocean. Based on megaflora, beetles, foraminifers, ostracodes, marine mollusks, and depositional structures from North Greenland (Funder et al., 1985; O. Bennike, pers. comm. 1989; E.M. Brouwers, pers. comm. 1989); on thawing and erosion on the Seward Peninsula of Alaska (Matthews, 1974); and on the replacement of tundra by forests in eastern Yakutia (Sher et al., 1979; Repenning, 1984), air and water temperatures were markedly warmer than today immediately after 2 million years ago. In Europe the Scandinavian Ice Sheet became greatly reduced 2.0 million years ago (Jansen et al., 1988), cold Praetiglian floras of the Netherlands gave way to the warm Tiglian floras (Zagwijn and de Jong, 1984), and subtropical sea surface temperatures may have existed near southwestern England (Jenkins et al., 1986).

The warm period that followed the first continental glaciation lasted from about 2.0 to at least 0.85 million years ago, with only minor variations in ice storage on land. However, this period of time is not yet well known throughout the Northern Hemisphere, and interpretations are troubled by uncertainties in temporal correlation.

Warm climates ended abruptly 850000 years ago. At that time the first glacial till of the classic Ice Age was deposited in the central United States (Easterbrook and Boellstorff, 1984). Perennial ice then clearly covered the Arctic Ocean (Herman and Hopkins, 1980) and the developing dominance of the Arctic High air mass not only facilitated continental glaciation but provided environments in which the mammalian fauna of the Ice Age, including the meadow mouse genus Microtus, could disperse southward throughout the Northern Hemisphere (Repenning, 1984). Perennial ice cover also evidently caused the return of tundra vegetation to the Arctic Ocean Borderland.
The pattern of climatic change appears to have been reversible and irregular. Meadow mouse dispersal routes do not appear reversible but they did change in an irregular pattern. These changes of dispersal routes appear at times of climatic change in the Arctic Ocean Borderland, as outlined below.

\section{MEADOW MOUSE DISPERSAL ROUTES}

From 6.5 million years ago until about 2.6 million years ago, all meadow mouse immigrants from Siberia, through Beringia, to the conterminous United States followed a route southward down the Pacific Coast on the western side of the Rocky Mountains of North America (Fig. 1). The oldest records of new immigrants are first known in the Pacific Northwest of the United States, and they appeared at specific times called dispersal events. These dispersal events, and the immigrants, are discussed by Repenning (1987).

Fossil faunas in the states of Washington, Oregon, Idaho, Wyoming, California, Nevada, Arizona, and Texas indicate that when these immigrants spread from the Pacific Coast to the east of the Rocky Mountains, they either went through a low pass from Idaho and across Wyoming to the Great Plains or went around the southern end of the Rocky Mountains through California, Nevada, Arizona, presumably New Mexico (no appropriate fossil faunas), and western Texas to the Great Plains. The Rocky Mountains have always been a barrier to meadow mouse dispersal and remain so today; the modern meadow mouse fauna is significantly different on opposite sides of the Rocky Mountains.

This dispersal route from Beringia down the Pacific Coast indicates that, at least until 2.6 million years ago, the Canada-

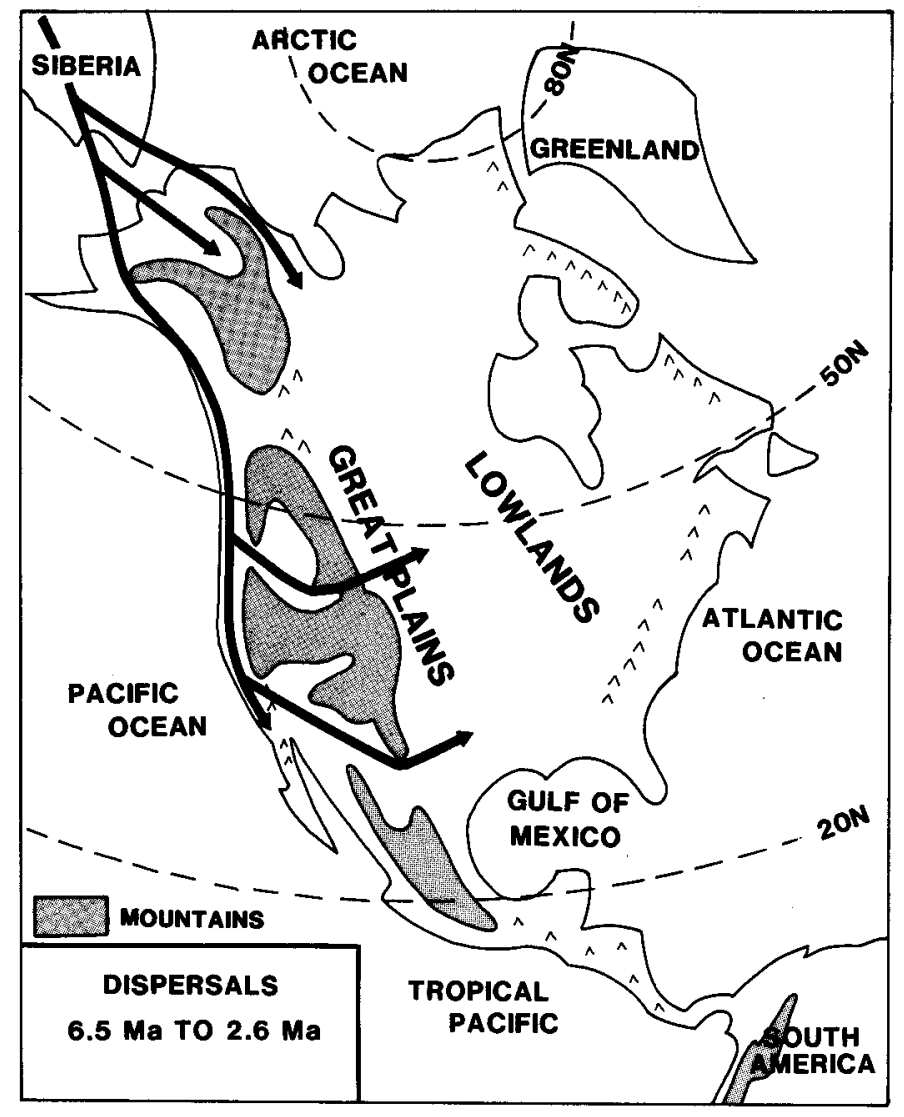

FIG. 1. Meadow mouse dispersal routes before 2.6 million years ago. 
Alaska Pacific Coast was very different from that of today. The coastal mountains apparently did not extend to the sea, and a coastal plain of some extent must have been present. From the grass utilization of most meadow mice, it can be assumed that such a coastal plain was open grassland or only sparsely forested, possibly comparable to coastal California of today.

One genus of "meadow mouse" came down the eastern side of the Rocky Mountains to the region of the Great Plains of the United States during the dispersal event 2.6 million years ago, very near the end of the Gauss Normal-polarity Chron. This was the first use of this route by a meadow mouse. The genus (Plioctomys) was a bog lemming, not a dry grassland form, and was presumably much more tolerant of a damp and forested environment; why it initiated this new dispersal route is not known. A close relative, derived from Plioctomys, came down the coastal route at this time but the cordilleran barrier kept them separate and distinct. By 2 million years ago the Pacific Coast immigrant dispersed around the southern end of the Rocky Mountains, through California, Arizona, and Texas, to the Great Plains and Plioctomys became extinct (Repenning and Grady, 1988).

In the next dispersal event, 1.8 million years ago and during the early part of the Olduvai Normal-polarity Subchron (dated in Holland; van Kolfschoten, 1988), four genera (Allophaiomys, Microtus, Phenacomys, and Proneofiber) dispersed southward along the eastern side of the Rocky Mountains. However, Microtus stopped at the southern boundary of Canada. Only Microtus and Phenacomys entered the United States by way of the western route (Fig. 2). This was the last time that any meadow mouse entered the United States by the coastal route west of the Rocky Mountains.

The next dispersal event did not occur until 850000 years ago, with the beginning of the Nebraskan ice advance; at this time all immigrants entered the conterminous United States by the route east of the Rocky Mountains. And with them Microtus first entered the United States east of the Rocky Mountains, having stopped at the southern border of Canada during the dispersal event 1 million years earlier.

This dispersal history correlates with uplift and erosion of the Chugach and Saint Elias mountains of southern Alaska and adjacent Canada.

\section{DELAYED DISPERSAL OF MICROTUS}

Of the four genera that came down the eastern side of the Rocky Mountains during the Olduvai event, three genera came all the way into the United States. As just mentioned, one genus, the living genus Microtus, stopped at the Canadian border (Fig. 2).

Microtus is first known about 2.2 million years ago in Siberian and Alaskan Beringia: in the Krestovka sections of Yakutia (Sher et al., 1979) and in Cape Deceit fauna of Alaska (Guthrie and Matthews, 1971; Fig. 3). The genus appeared about 1.5 million years ago in the higher latitudes of Europe (Musil, 1966), Canada (Churcher, 1984), and the Pacific Coast of the United States (Zakrzewski, 1972). At this time one species is known in southern Saskatchewan (Wellsch Valley fauna, Fig. 3), one in Czechoslovakia, and one in southern California. However none is known to the south in the United States east of the Rocky Mountains or in southern Europe until the time of the first Nebraskan ice

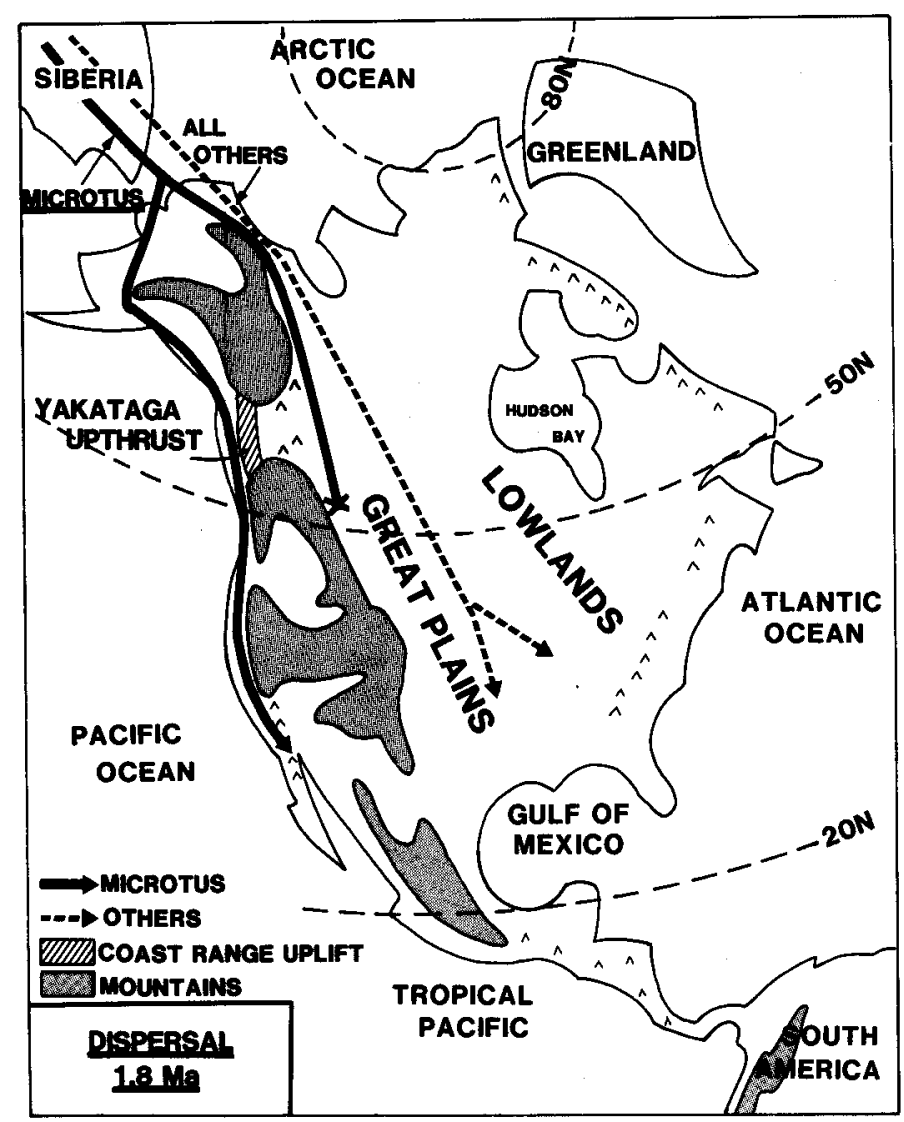

FIG. 2. Meadow mouse dispersal routes 1.8 million years ago showing the last use of the western route, by Microtus, and the failure of this genus to penetrate the United States east of the Rocky Mountains with other meadow mice.

advance 850000 years ago, almost 1 million years later (Repenning and Grady, 1988).

The southernmost European record before 850000 years ago is from Holstejn, Czechoslovakia (latitude $49^{\circ} 24^{\prime}$ north; Musil, 1966; Fejfar and Horacek, 1983). This is a fossil fauna that contains Allophaiomys pliocaenicus and the very primitive Microtus ratticepoides. In western Europe Allophaiomys became extinct before the Jaramillo event (before 0.97 million years ago; van Kolfschoten, 1988).

In the United States to the east of the Rocky Mountains, the three genera that continued their southward dispersal represented the ancestors of 1) the living heather and tree voles (Phenacomys), which are browsers and not dependent on grass; 2) the living round-tailed muskrats (Neofiber), which are aquatic and now subtropical in habit; and 3) Allophaiomys, an extinct genus whose closely related descendant (Phaiomys leucurus) now inhabits high, damp alpine meadows in the Himalayas and the Tibetan Plateau.

There is a remarkable belt of late-arriving Microtus around the world south of the latitude of $50^{\circ}$ north. In China the earliest record is about 800000 years old at about latitude $40^{\circ}$ north (Zheng and $\mathrm{Li}$, in press). In India the oldest record is perhaps 700000 years old at about latitude $34^{\circ}$ north (Repenning, 1984). In southern European U.S.S.R. it is about 850000 years ago at about latitude $47^{\circ}$ north (Karay-Dubina locality in the Ukrainia and Shamin locality in southern Russia; Markova, 1982). In Israel the earliest record is also perhaps 700000 years old at about latitude $32^{\circ}$ north (Tchernov, 1979). In Italy the oldest record of Microtus is 


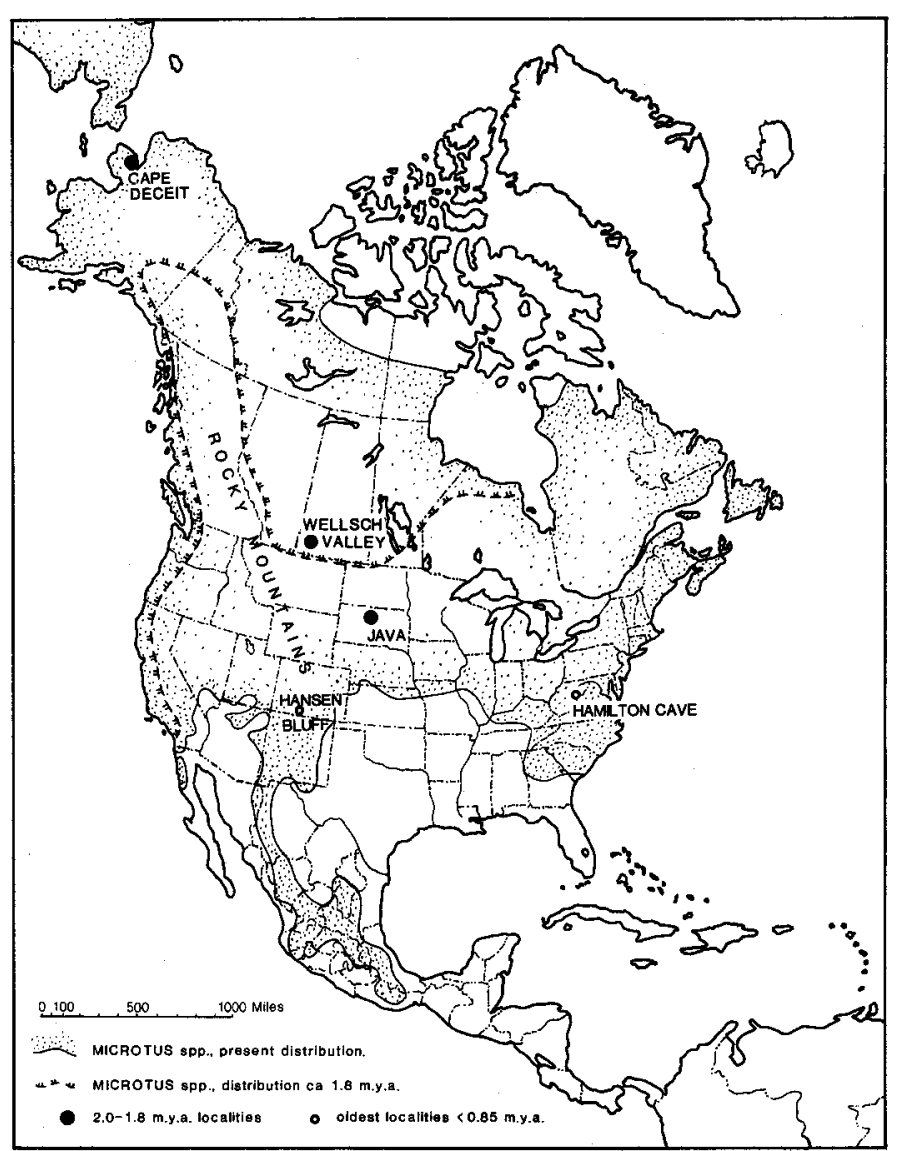

FIG. 3. Modern distribution of the genus Microtus in North America compared with the approximate distribution of this genus 2 million years ago.

about 800000 years old at about latitude $42^{\circ}$ north (Coltorti et al., 1982). In southern Spain Microtus first appeared about 800000 years ago at about latitude $38^{\circ}$ north (Agusti et al., 1987).

In North America this wave of late-arriving Microtus is also present to the east of the Rocky Mountains, as has been mentioned. The genus arrived in Canada on schedule, nearly 2 million years ago, where it is present in the Wellsch Valley fauna of southwestern Saskatchewan (Churcher, 1984; about latitude $50^{\circ} 39^{\prime}$ north). South of Canada and east of the Rocky Mountains the earliest records of Microtus are from West Virginia and southern Colorado. The West Virginian record is perhaps 840000 years old and at about latitude $38^{\circ}$ north (Repenning and Grady, 1988), and the Colorado record is about 820000 years old and at about latitude $38^{\circ}$ north (Rogers et al., 1985).

A comparable climatic and faunal range variation at this time is also recorded in Europe. It has been mentioned that Microtus entered Europe and extended as far south as Czechoslovakia (latitude $49^{\circ} 24^{\prime}$ north) more than 1 million years ago, where it is associated with the genus Allophaiomys; it has also been mentioned that Allophaiomys became extinct in Europe before the Jaramillo event. However, in the North Sea area (Holland, latitude $52^{\circ}$ north, van Kolfschoten, 1988) Microtus does not appear until less than a million years ago, after the European extinction of Allophaiomys. Mention has also been made that subtropical sea surface temperatures possibly were present near southwestern England about 2 million years ago (Jenkins et al., 1986). It would seem that the warmer North Atlantic Ocean made coastal Europe intolerable to Microtus until just before the Ice Age.

Throughout the Northern Hemisphere the only exception to this low-latitude late arrival of Microtus is in California, where Microtus appeared about 1.5 million years ago (Zakrzewski, 1972). In contrast to its dispersal down the eastern side of the Rocky Mountains, west of the Rocky Mountains Microtus continued southward at least to latitude $33^{\circ}$ north, almost to Mexico. Presumably the maritime climate of the Pacific Coast was more agreeable than elsewhere in the lower latitude Northern Hemisphere. Today this immigrant species of Microtus is still confined to Pacific Coast climate and lives only in western Oregon, California, and northern Baja California, although it is known to have spread eastward to Las Vegas, Nevada, during the last glaciation (Mawby, 1967). Microtus and Phenacomys were the only genera to enter the United States along the western (Pacific Coast) route at this time and were the last meadow mice to use this route.

The circum-global delay in the southward dispersal of Microtus suggests a hemispheric climatic condition, nullified only by the maritime climate of the Pacific Coast. An inference of the nature of this climatic control can be made in North America by consideration of the constraints on the modern distribution of the genus (Fig. 3). To the east of the Mississippi River, with minor exception, the present southward distribution of the meadow mouse Microtus appears to be limited by the maximum of $1200 \mathrm{~mm}$ of mean annual precipitation from South Carolina to central Kentucky. To the west of Kentucky, where mean annual rainfall drops below $1000 \mathrm{~mm}$, the southern limit of the range of Microtus follows the maximum July average daily temperature of $25^{\circ} \mathrm{C}$ to New Mexico, approaching $26^{\circ} \mathrm{C}$ in humid localities, such as along the Missouri and Mississippi rivers. The rapidly decreasing precipitation from Kentucky to New Mexico does not seem to affect its distribution.

The distribution of the genus thus appears to be constrained both by excessive rainfall and heat, although in that part of the Atlantic coastal plain having more than $1000 \mathrm{~mm}$ of rainfall, it appears that the genus is able to endure July average daily temperatures about two degrees hotter (around $27^{\circ} \mathrm{C}$ ) than in regions with less than about $1000 \mathrm{~mm}$ annual precipitation. Thus the genus avoids the Atlantic coastal plain south of South Carolina because of excessive rainfall and the Gulf states west of the Mississippi River because of excessive summer temperatures. Presumably the Great Plains of southern Canada did not exceed the limit of a maximum July average daily temperature of $25^{\circ} \mathrm{C}$ about 2 million years ago, but localities to the south in the United States did.

The most northerly control point south of the 1.5 millionyear-old range of Microtus is the Java fauna in northern South Dakota (Martin, 1989), $564 \mathrm{~km}$ farther south than the Wellsch Valley fauna of southern Saskatchewan. Unlike the Wellsch Valley fauna, the Java fauna (latitude $45^{\circ} 26^{\prime}$ north) lacks Microtus but contains the cotton rat (Sigmodon, a non"meadow mouse" rodent), indicating that winter freezes were uncommon (Martin, 1989). This is the northernmost record of the cotton rat, fossil or living. The modern distributions of Microtus and Sigmodon are almost mutually exclusive, although one appears to be regulated by excessive summer temperature and the other by minimum winter temperature.

As indicated by the fossil reptiles and amphibians in the Java fauna (Holman, 1977), South Dakota clearly had greater rainfall about 1.5 million years ago than today, but probably 
less than $800 \mathrm{~mm}$ per year. Thus excessive summer temperature, rather than too much annual precipitation, was probably responsible for the failure of Microtus to enter the Great Plains of the United States following the end of continental glaciation 2 million years ago.

A climate comparable to that of modern St. Louis, Missouri, existed on the Great Plains between southern Saskatchewan and northern South Dakota immediately following the first continental glaciation of North America. These conditions appear to have persisted for about 1 million years, as Microtus did not enter the United States from Canada until about 850000 years ago, during the first of several ice sheets that have been called "Nebraskan."

\section{THE YAKATAGA FORMATION}

The most recent accretion to the Canada-Alaska coastline has been the Yakutat terrane in the Chugach and Saint Elias mountains of southern Alaska; this terrane includes the Yakataga Formation (shown as "Yakataga upthrust" on Fig. 2). The Yakataga Formation is a unit of marine sediments deposited in the Gulf of Alaska and is at least $5000 \mathrm{~m}$ thick; it ranges in age from possibly 16 million years to younger than 1.5 million years, depending upon how the formation is defined (Armentrout, 1983; Marincovich, 1989). Similar deposition has continued to the present time and some consider this to be a continuation in the deposition of the Yakataga Formation (Plafker and Addicott, 1976).

The Yakataga Formation records close to twice the time that is represented in the entire history of meadow mice, as well as about 16 million years of the history of deformation that occurred as the Pacific plate moved against North America. The marine deposits of the formation are composed of the debris that washed off the rising Chugach and Saint Elias mountains. When the glaciers in these mountains flowed to the sea, the resulting icebergs carried dropstones away from shore and they are now found in the Yakataga Formation.

Beginning 15 or 16 million years ago (Marincovich, 1989), in the middle Miocene, three periods of upthrusting raised the Chugach and Saint Elias mountains high enough to encourage mountain glaciation that extended to the sea. These glacial periods are recorded by three zones containing dropstones in the Yakataga Formation. During the following 12 million years or more, $600 \mathrm{~m}$ of marine deposits with no evidence of drifting ice (dropstones) were added to the Yakataga sedimentary mass. If mountain glaciation existed between about 15 and 2.6 million years ago, as it presumably did, the ice did not reach the sea (Armentrout, 1983). During this time and at least until 2.6 million years ago, meadow mice moved southward along the Pacific Coast from Beringia to the conterminous United States.

That part of the Yakataga Formation younger than about 2.6 million years old, and that can be examined on land, is glaciomarine. The older $300-400 \mathrm{~m}$ of this part of the outcrop section is marked by ice-rafted dropstones, indicating ice flowing to the sea, and the rest is characterized by multiple fjord channels filled with glaciomarine sediments, indicating protracted and profound glacial movement to and into the sea, scouring coastal bottom sediments of the sea. If global climate was comparable with that of today, between 2.6 and perhaps 2.0 million years ago, the amount of uplift of the Chugach and Saint Elias mountains that was needed to support ice fields capable of such fjord development would seem to have been equal to or greater than that which supports the glaciers of today, which are now withdrawing from the shore.

A marine diatom flora, now about $1100 \mathrm{~m}$ above sea level, lived during the early part of the fjord cutting and filling stage; this flora is between 2.47 and 2.2 million years old (John A. Barron, pers. comm. 1987). With the single exception of the dispersal of Microtus and Phenacomys to California before 1.5 million years ago (presumably about 1.8 million years ago), meadow mice no longer used the Pacific Coast dispersal route west of the Rocky Mountains after the time of the diatom flora in the Yakataga Formation. Rivers of ice, extending from the mountain tops to the sea, blocked their way in southern Alaska and continuous uplift was bringing the mountains to the sea, destroying what must have been a habitable coastal grassland.

These conditions suggest a correlation between the beginning of fjord development and the end of meadow mouse dispersal, as well as agreement between rodent and diatom biochronologies. Conversely, the dispersal of Microtus to southern California before 1.6 million years ago suggests that fjords were not actively forming at this time, as the mice were able to negotiate the rising coastal mountains and move southward for a final time. This final dispersal down the Pacific Coast route to the United States correlates with the warm climate that was recorded in the Arctic Ocean Borderland after the first continental glaciation of North America, terminating 2.0 million years ago (Repenning and Browers, in preparation).

Ultimately, after the dispersal of Microtus to California (presumably 1.8-1.6 million years ago), uplift of the Chugach and Saint Elias mountains permanently closed the route of southward dispersal west of the cordillera for all meadow mice and also exposed part of the Yakataga Formation above sea level. This uplift may have been a factor in the development of the Ice Age glaciations of North America.

\section{CHANGES IN CLIMATE}

Bryson and Hare (1974) diagrammatically illustrate three major courses by which the cordillera is crossed by modern low-level air flow of the Pacific westerlies (averaging below $2 \mathrm{~km}$ or $800 \mathrm{mb}$ at sea level). Two of these resemble the routes of meadow mouse dispersal from west of the Rocky Mountains to the Great Plains: around the southern end of the Rockies or across the low pass through Wyoming (Fig. 1). Farther north, the third is not a mouse route, for it consists of piling up the westerlies against the cordilleran wall until they spill over onto the east side, a process that feeds the ice fields in the Chugach and Saint Elias mountains, as well as those in the Canadian Coast Mountains.

Figure 4 suggests a possible low-level wind pattern before 2.6 million years ago when the Yakataga Formation received no dropstones from mountain glaciers that flowed to the Gulf of Alaska and when immigrating meadow mice first appeared in the Pacific Northwest of the United States (following the dispersal route shown in Fig. 1). The wind pattern at this time differed little from that of today, but without the higher topographic barrier of the Chugach and Saint Elias mountains the strongest of the Pacific westerlies would have carried warm and wet Pacific air across Canada, air much less modified by the coastal mountains than it is today. The Canadian Arctic would have received much of the winter 


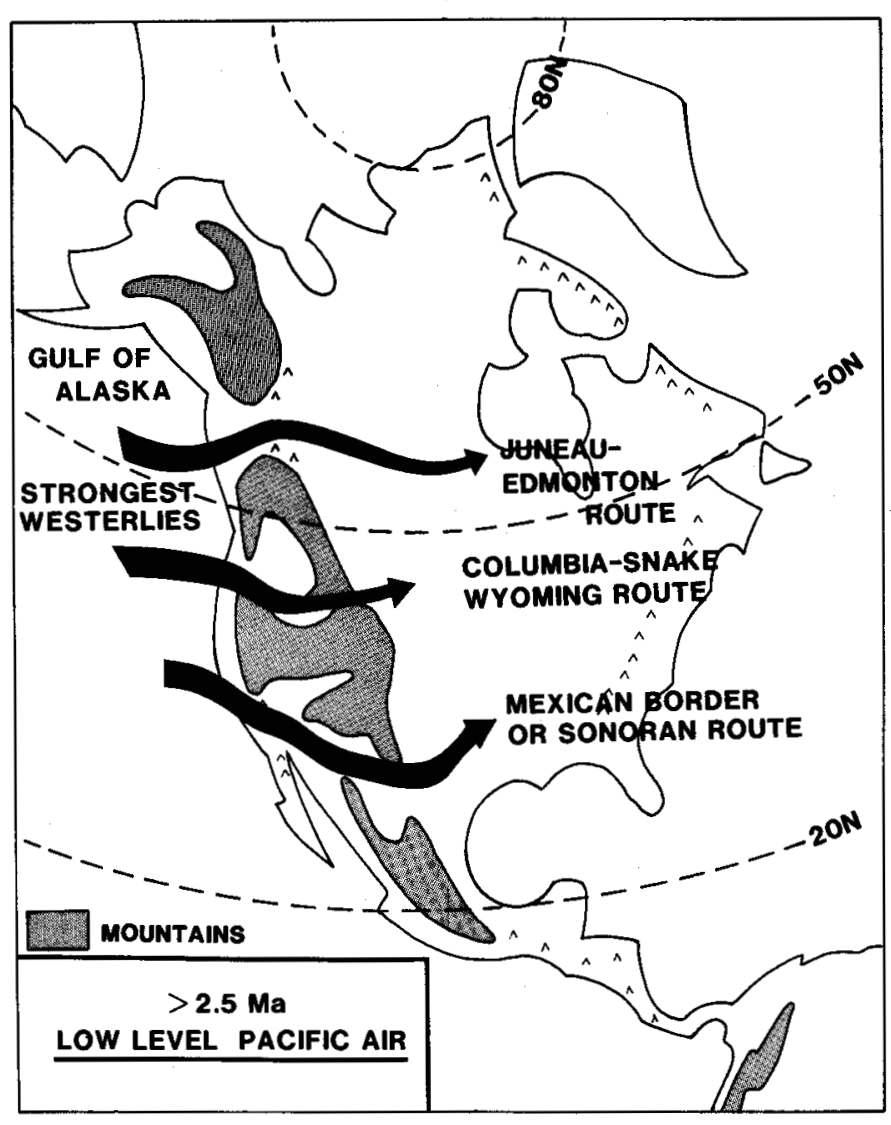

FIG. 4. Possible routes that the Pacific westerlies may have taken to cross the Rocky Mountains more than 2.6 million years ago.

weather that now is diverted into a cyclone over the Gulf of Alaska, from Juneau to Kodiak Island. Edmonton, now in the Canadian Great Plains, might have been forested.

Forest in the position of the present Canadian plains would have been a dispersal barrier to most grassland mammals, including meadow mice, and they did not disperse southward along the eastern side of the Rocky Mountains more than 2.6 million years ago.

As the Chugach and Saint Elias mountains were uplifted, and as this history of uplift was recorded first in the renewed deposition of dropstones in the Yakataga Formation and then in the formation of multiple fjord channels, restraint and deflection of the Pacific westerlies would have increased. Those westerlies that crossed the rising mountains would have been increasingly milked of moisture, feeding glaciers that flowed back to the sea rather than forests at Edmonton. After about 2.5 million years ago, the glaciers in the coast ranges must have reached the sea, because ice-rafted dropstones and then, by perhaps 2.4 million years ago, fjord channels appeared in the Yakataga Formation. By that time the rising rain shadow of the uplift would have caused grasslands at Edmonton, and the glaciers of the Chugach and Saint Elias mountains would have made meadow mouse dispersal down the Pacific Coast impossible.

One factor seems to have delayed the development of grasslands at Edmonton, the growth of the first North American continental glaciation and the development of a peripheral front about its margins. This ice sheet seems to have begun accumulating by about 2.56 million years ago, to judge from the contemporaneous history of the Scandinavian ice sheet (Jansen et al., 1988).
It is not certain that the Arctic Ocean was frozen between 2.56 and 2.0 million years ago; before 2.4 million years ago freezing seems unlikely, at least near shore; between 2.4 and 2.1 million years ago arctic air temperatures were at times warmer than today; throughout the entire period, between 2.56 and 2.0 million years ago, planktonic foraminifera in the central Arctic Ocean indicate warmer surface water temperatures than seem compatible with ice cover (Herman et al., 1989); and shortly before 2.0 million years ago the ocean must have been unfrozen at least part of the year in northernmost Greenland, about 500 miles from the North Pole (Repenning and Brouwers, in press). A low-pressure atmosphere would have been centered over the unfrozen Arctic Ocean in the winter, caused by oceanic warming and moistening of the atmosphere; in the summer a weak high-pressure system would have existed while the ocean was being warmed by 24-hours-a-day insolation.

Despite the indication of an unfrozen or intermittently frozen Arctic Ocean between 2.56 and 2.0 million years ago, the first significant continental glaciation of the Northern Hemisphere extended to southern Iowa. Its maximum extent is well dated as being 2.1 million years old (Easterbrook and Boellstorff, 1984) and correlates well with the date of the maximum glaciation of the Scandinavian ice sheet (Jansen et al., 1988). Possibly the weakening of the Pacific westerlies by the Chugach and Saint Elias mountains allowed North Atlantic subtropical air to enter eastern Canada during the winter and moist Arctic Ocean air during the summer, both feeding a Laurentide ice cap.

No meadow mice entered the United States during this glaciation. Watered by the frontal system marginal to the ice sheet, the inferred forests of Edmonton must have continued to block the eastern dispersal route and the Yakataga fjords certainly blocked the coastal route. Figure 5 shows a hypothetical reconstruction of low-level winds and ice distribution at this time.

The oxygen isotope record suggests that this first continental glaciation of the Northern Hemisphere formed, decayed, and rejuvenated at least three times between 2.4 and 2.0 million years ago, possibly reflected in variations of seasonal Arctic Ocean ice cover, and that it vanished 2.0 million years ago (Shackleton et al., 1984). In addition to the oxygen isotope record, there are a number of other indications of warming after 2.0 million years ago: 1) Microtus crossed the area of the Yakataga fjords presumably about 1.8 million years ago, and certainly before about 1.5 million years ago, to disperse to California; 2 ) at the same time four meadow mouse genera, including Microtus, dispersed southward down the eastern side of the Rocky Mountains and suggest the development of grasslands in the Canadian Great Plains with the loss of the Laurentide ice sheet (Fig. 5); 3) records from the Seward Peninsula of Alaska, northern Greenland, and northeastern Siberia suggest that the Arctic Ocean region became much warmer than today beginning about $\mathbf{2 . 0}$ million years ago; 4) records from the Norwegian Sea indicate that glaciation in Scandinavia became greatly reduced beginning 2 million years ago (Jansen et al., 1988); 5) sea surface temperatures around Cornwall, England, are inferred to have become warmer, possibly subtropical, 2 million years ago (Jenkins et al., 1986); and 6) the Central Plains of the United States contain glacial tills that are about the same age as the Yakataga diatom flora, but deposition of these tills stopped 


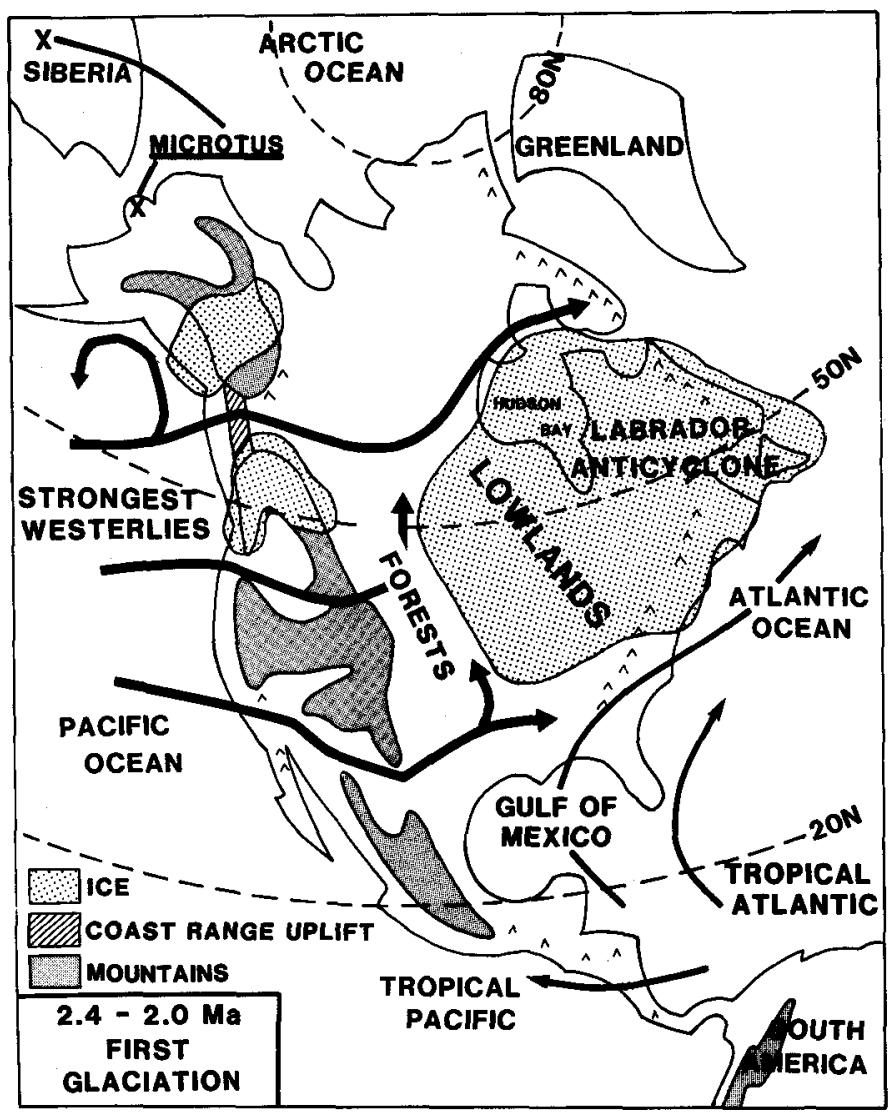

FIG. 5. Possible routes of low-level air movement between 2.4 and 2.0 million years ago, inferred location of the first significant continental glaciation of the Northern Hemisphere, and known distribution of Microtus at that time. Atlantic tropical air shown in lighter arrows.

between 2.1 and 2.0 million years ago (Easterbrook and Boellstorff, 1984).

The warming of the climate and the termination of continental glaciation 2 million years ago, permitting the renewed southward dispersal of meadow mice, are not recorded in the outcrops of the marine Yakataga Formation. The outcrops of the Yakataga Formation that are younger than the 2.47- to 2.2-million-year-old diatom flora consist only of filled fjord channels. This indicates a continuation of extensive glaciation of the Alaskan-Canadian coast ranges and, thus, of the barrier that modified the Pacific westerlies and blocked meadow mouse dispersal southward down the Pacific Coast west of the Rocky Mountains. All of the Yakataga exposed on the mainland would thus seem to be older than about 2 million years. The formation has been thrust above sea level since that time, indicating renewed orogenic obstruction of the Pacific westerlies.

The warming of the Arctic Ocean region 2 million years ago may have resulted from a slowing of uplift and a lowering of the topography of the Chugach and Saint Elias mountains by the preceding half million years of intensive glacial activity that produced multiple fjords in the Yakataga Formation. However, glacial erosion from perhaps 2.6-2.0 million years ago must have only partially lowered the coastal mountains, otherwise forests would have remained in Edmonton and grassland meadow mice would not have dispersed down the eastern side of the Rocky Mountains. A rain shadow had to have been maintained, but a more effective Pacific air mass must have been present over Canada to hold back moist Atlantic air in the winter and moist arctic air in the summer, starving continental glaciation.

Forests could then spread to northernmost Greenland under the winter influence of the Atlantic tropical air mass, which was: 1) less influenced by the Pacific westerlies than it was 3 million years ago; 2) no longer influenced by the atmospheric high of a Labrador ice sheet; 3 ) encouraged to spread northward by the winter arctic low-pressure system over the unfrozen Arctic Ocean; and 4) centered farther north than its modern position, as suggested by subtropical seasurface waters 2 million years ago in the vicinity of Cornwall, England (Jenkins et al., 1986), by a great reduction in activity of the Scandinavian Ice Sheet at this time (Jansen et al., 1988), and by the development of the warm Tiglian flora of the Netherlands (Zagwijn and de Jong, 1984).

In the summer the weak Arctic High above the warming ocean would have reversed the wind flow, bringing additional moisture to Kap København from the Arctic Ocean. Estimated climatic parameters, based upon the fossil flora in the youngest part of the Kap København Formation (2.0 million years old), suggest a $13^{\circ} \mathrm{C}$ increase in winter temperature (coldest monthly mean), an $11^{\circ} \mathrm{C}$ increase in summer temperature (warmest monthly mean), and a $530 \mathrm{~mm}$ increase in annual precipitation.

With the hypothetical introduction of grasslands around Edmonton, meadow mice could disperse southward onto the Great Plains of Canada and the United States. However, explanation of the fact that Microtus stopped at the United States border requires additional interpretation.

During the first significant glaciation of North America, 2.6-2.0 million years ago, the meadow mouse Microtus evolved in Siberia; earliest records of Microtus in both Siberian and Alaskan Beringia are close to 2.2 million years old. Immediately following the decay of the first Northern Hemisphere glaciation, Microtus spread into Canada and into northern Europe. Over 1 million years later it dispersed southward around the entire Northern Hemisphere: into the United States east of the Rocky Mountains, and into central China, northern India, southern Russia, Israel, central Italy, and southern Spain. The 1-million-year delay is contemporaneous with climatic changes that have been discussed; this delay implies that unacceptable environments existed south of about latitude $50^{\circ}$ north around the Northern Hemisphere.

In the case of North America, the possibility has already been considered that the rising Chugach and Saint Elias mountains deflected the strongest westerlies and formed a rain shadow that resulted in grassland in the present Canadian plains. If Microtus was an arctic to temperate grassland mammal then, as it is today, it would have spread into the new grasslands as far south as temperate conditions extended. Beginning 2.0 million years ago, and lasting until the Arctic Ocean froze, the maximum expansion was approximately to the Canadian-United States border in the present Great Plains area. As discussed, this marks a southern limit of tolerable summer temperature, a temperature limit now found in the vicinity of St. Louis, Missouri. This, in turn, suggests that the Great Plains of the United States were not temperate grasslands after 2.0 million years ago, but were subtropical savannah with a July average daily temperature above $25^{\circ} \mathrm{C}$; rainfall also appears to have been higher but no more than $800 \mathrm{~mm}$ per year. 
In combination with the 2.0- to 1.8-million-year-old records from Greenland, Norway, and northwestern Europe, shortly following the first continental glaciation of North America, it would seem that lack of an Arctic High, because of an unfrozen, or intermittently frozen, Arctic Ocean, and the northward expansion of the North Atlantic subtropical highpressure system, the Bermuda High of today, also allowed the present climate of the Gulf of Mexico region to extend northward. Because of the indicated climates in southern Saskatchewan and northern South Dakota at this time, the Bermuda High of 2.0-1.8 million years ago presumably extended northward along the eastern face of the Rocky Mountains in the United States, as far north as the Canadian border. Based upon the fossil fauna, estimated climatic parameters of the Java fauna of northern South Dakota (about 1.6 million years old) suggest a $14^{\circ} \mathrm{C}$ increase in winter temperature (coldest monthly mean), a $7^{\circ} \mathrm{C}$ increase in summer temperature (warmest monthly mean), and a 300 $\mathrm{mm}$ increase in annual precipitation.

From the region of the Dakotas, the North Atlantic subtropical high-pressure air mass would have moved northeastward across eastern Canada, in the winter reaching northward to northern Greenland, Norway, and northwestern Europe because of the Arctic Low. Because of the weak Arctic High in the summer, it would have had a more limited northward extent, producing fewer warming effects; but winds off of the unfrozen Arctic Ocean would still contribute moisture.

Figure 6 provides a reconstruction of the winter atmospheric elements of North America following the decay of the first significant continental glaciation 2.0 million years ago. With an Arctic Low drawing in air from the south and with only some deflection of the Pacific westerlies by the Chugach and Saint Elias mountains, the North Atlantic tropical air mass would have extended much farther north across the United States than before the Yakataga uplift. Before this uplift the Pacific westerlies controlled Canada. After the freezing of the Arctic Ocean and the creation of a winter Arctic High, beginning 850000 years ago, the arctic air mass controlled Canada and half of the United States in the winter.

The classic glaciations of the Northern Hemisphere began 850000 years ago with the freezing of the Arctic Ocean, which caused reduced insolation in the summer and also insulation of the Arctic Ocean's heat in the winter. Atlantic subtropical air was forced southeastward in North America because of the development of a strong arctic air mass, strengthened by a chilling of the northern part of the North Atlantic. Grasslands, and associated Microtus, then became established in the United States east of the Rocky Mountains, in southern Europe and Asia, and along the European Atlantic Coast.

Although glacier fields in the Chugach and Saint Elias mountains of southern Alaska and adjacent Canada have been retreating in recent years, to judge by glacial development and assuming other climatic factors are similar, the elevation of these mountains appears to be almost as great as it was $\mathbf{2 . 5 6}$ million years ago, when the first continental glaciation of North America was initiated. Therefore, it seems to be a debatable question whether the melting of the ice cover of the Arctic Ocean by "greenhouse" warming will cause another continental glaciation of the northern hemi-

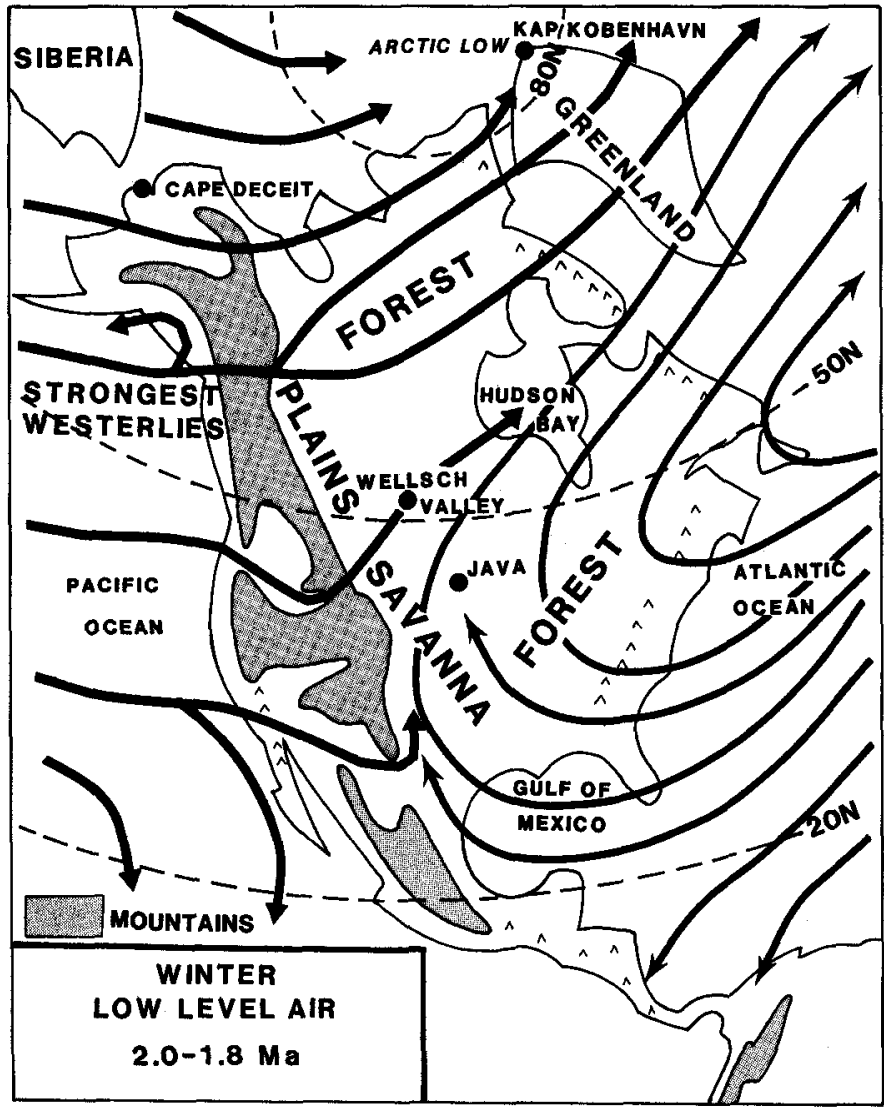

FIG. 6. Possible winter low-level air movement between 2.0 and 1.8 million years ago with an Arctic Low. Heavy arrows represent westerly winds.

sphere, as it did 2.56 million years ago, or trees to grow in northernmost Greenland, as occurred 2.0 million years ago. Or both.

Much seems to depend on the Greenland ice cap, which does not seem removable in 100 years; its presence does not favor so great a northward extension of Atlantic subtropical air as is evident 2 million years ago, and it favors considerable precipitation in Laurentia.

\section{ACKNOWLEDGEMENTS}

Particular thanks are due to John M. Armentrout, Mobil Oil Corporation, for sharing his knowledge of the Yakataga Formation and to Robert S. Thompson, U.S. Geological Survey, for sharing his thoughts about climatic patterns; however, the assumptions made in this hypothesis are my own. The key locality for understanding the climatic history of the Arctic Ocean Borderland are those sections in Yakutia near the junction of the Krestovka River with the Kolyma River that have been investigated by Andrei V. Sher and his associates from the Academy of Science of the U.S.S.R.; although we have some differences of opinions, none of this and other syntheses could have been made without the information that Dr. Sher has provided.

John V. Matthews, Jr., Geological Survey of Canada, has continuously provided information used in these inferences, although he does not necessarily agree with them. I have profited from discussions and correspondence regarding the Kap Kobenhavn Formation with Ole Bennike and Svend Funder of Denmark. Elisabeth M. Brouwers, J. Platt Bradbury, Louie Marincovich, Jr., and Robert S. Thompson all reviewed the manuscript and I thank them for their help. Two anonymous reviewers helped greatly by pointing out places in the manuscript where further explanation was needed. 


\section{REFERENCES}

AGUSTI, J., MOYA-SOLA, S., and PONS-MOYA, J. 1987. La sucesion de Mamiferos en el Pleistoceno inferior de Europa: proposicion de una nueva escala bioestratigrafica. Paleontologia i Evolucio, Memoria Especial 1:287-295.

ARMENTROUT, J.M. 1983. Glacial lithofacies of the Neogene Yakataga Formation, Robinson Mountains, Southern Alaska Coast Range, Alaska. In: Molnia, B.F., ed. Glacial-Marine Sedimentation. New York: Plenum Press. 629-665.

BENNIKE, O., and BÖCHER, J. 1990. Forest-tundra neighbouring the North Pole: plant and insect remains from the Plio-Pleistocene Kap Køobenhavn Formation, North Greenland. Arctic 43(4):331-338.

BRYSON, R.A., and HARE, F.K. 1974. The climates of North America. In: Bryson, R.A., and Hare, F.K., eds. Climates of North America. Amsterdam: Elsevier Scientific Publishing Company. 1-47.

CHURCHER, C.S. 1984. Faunal correlation of Pleistocene deposits in western Canada. In: Mahaney, W.C., ed. Correlation of Quaternary chronologies. Norwich: Geo Books. 145-158.

COLTORTI, M., CREMASCHI, M., DELITALA, M.C., ESU, D., FORNASERI, M., MCPHERRON, A., NICOLETTI, M., VAN OTTERLOO, R., PERETTO, C., SALA, B., SCHMIDT, V., and SEVINK, J. 1982. Reversed magnetic polarity at an early Lower Paleolithic site in Central Italy. Nature 300:173-176.

EASTERBROOK, D.J., and BOELLSTORFF, J. 1984. Paleomagnetism and chronology of early Pleistocene tills in the central United States. In: Mahaney, W.C., ed. Correlation of Quaternary chronologies. Norwich: GeoBooks. 73-90.

FEJFAR, O., and HEINRICH, W.-D. 1983. Arvicoliden-Sukzession und Biostratigraphie des Oberpliozans in Quatars in Europa. Schriftenreihe fur geologische Wissenschaften, Berlin 19/20:61-109.

FEJFAR, O., and HORACEK, I. 1983. Zur Einwicklung der Kleinsaugerfaunen im Villanyium und Alt-Biharium auf dem Gebiet der CSSR. Schriftenreihe fur geologische Wissenschaften-Berlin 19/20:111-207.

FUNDER, S., ABRAHAMSEN, N., BENNIKE, O., and FREYLINGHANSSEN, R.W. 1985. Forested arctic - evidence from North Greenland. Geology 13:542-546.

GITERMAN, R.E., SHER, A.V., and MATTHEWS, J.V., Jr. 1982. Comparison of the development of tundra-steppe environments in west and east Beringia: pollen and macrofossil evidence from key sections. In: Hopkins, D.M., Matthews, J.V., Jr., Schweger, C.E., and Young, S.B., eds. Paleoecology of Beringia. New York: Academic Press. 43-73.

GUTHRIE, R.D., and MATTHEWS, J.V., Jr. 1971. The Cape Deceit fauna - early Pleistocene mammalian assemblage from the Alaskan Arctic. Quaternary Research 1:474-510.

HERMAN, Y., and HOPKINS, D.M. 1980. Arctic Ocean climate in late Cenozoic time. Science 280:557-562.

HERMANY, Y., OSMOND, J.K., and SOMAYAJULU, B.L.K. 1989. Late Neogene arctic paleoceanography: micropaleontology, stable isotopes and chronology. In: Herman, Y., ed. The Arctic Seas, climatology, oceanography, geology, and biology. New York: Van Nostrand Reinhold. 581-655.

HOLMAN, J.A. 1977. America's northernmost Pleistocene herpetofauna (Java, north-central South Dakota). Copeia, Herpetological Notes 1:191-193.

JANSEN, E., BLEIL, U., HENRICH, R., KRINGSTAD, L., and SLETTEMARK, B. 1988. Paleoenvironmental changes in the Norwegian Sea and the Northeast Atlantic during the last 2.8 m.y.: Deep Sea Drilling Project/Ocean Drilling Program Sites 610, 642, 643, and 644. Paleoceanography 3:563-581.

JENKINS, D.G., WHITTAKER, J.E., and CARLTON, R. 1986. On the age and correlation of the St. Erth Beds, S.W. England, based on planktonic foraminifera. Journal of Micropaleontology 5:93-105.

van KOLFSCHOTEN, T. 1988. The Pleistocene mammalian faunas from the Zuurland boreholes at Brielle, The Netherlands. Mededelingen van de Werkgroep voor Tertiaire en Kwartaire Geologie 25:73-86.

MARINCOVICH, L., Jr. 1989. Tectonically-induced early Middle Miocene marine glaciation and molluscan faunas in the Gulf of Alaska. Geological Society of America, Abstracts with Programs (St. Louis): All5.
MARKOVA, A.K. 1982. Pleistocene rodents of the Russian Plain. Moscow: Academy of Sciences of the U.S.S.R., Nauka. 186 p. In Russian.

MARTIN, R.A. 1989. Arvicolid rodents of the early Pleistocene Java local fauna from north-central South Dakota. Journal of Vertebrate Paleontology 9:438-450.

MATTHEWS, J.V., Jr. 1974. Quaternary environments at Cape Deceit (Seward Peninsula, Alaska) - evolution of tundra ecosystems. Geological Society of America Bulletin 85:1353-1384.

MAWBY, J.E. 1967. Fossil vertebrates of the Thule Springs site, Nevada. Nevada State Museum, Anthropological Papers No. 13, part 2:106-128.

MUSIL, R. 1966. Holstejn, eine neue altpleistozane Lokakitat in Mahren. CasopisMoravckeho Musea v Brno Acta Musei Moraviae, Vedy Prirodni - Scientiae Naturales, Brno 51:133-168.

PLAFKER, G., and ADDICOTT, W.O. 1976. Glaciomarine deposits of Miocene through Holocene age in the Yakataga Formation along the Gulf of Alaska margin, Alaska. In: Miller, T.P., ed., Recent and ancient sedimentary environments in Alaska. Proceedings of the Alaska Geological Society Symposium, April 2-4, 1975, Anchorage: Q1-Q22.

REPENNING, C.A. 1984. Quaternary rodent biochronology and its correlation with climatic and magnetic stratigraphies. In: Mahaney, W.C., ed. Correlation of Quaternary chronologies. Norwich: GeoBooks. 105-118. 1987. Biochronology of the microtine rodents of the United States. In: Woodburne, M.O., ed. Cenozoic mammals of North America: geochronology and biostratigraphy. Berkeley: University of California Press. 236-268.

REPENNING, C.A., and BROUWERS, E.M. 1987. Mid-Pliocene to latePleistocene changes in the Arctic Ocean Borderland ecosystem. International Union for Quaternary Research, XII International Congress, Program with Abstracts, p. 251.

REPENNING, C.A., and GRADY, F. 1988. The microtine rodents of the Cheetah Room fauna, Hamilton Cave, West Virginia, and the spontaneous origin of Synaptomys. U.S. Geological Survey Bulletin 1853. $32 \mathrm{p}$.

REPENNING, C.A., RAY, C.E., and GRIGORESCU, D. 1975. Pinniped Biogeography. In: Gray, J., and Boucot, A.J., eds. Historical biogeography, plate tectonics, and the changing environment. Corvallis: Oregon State University Press. 357-369.

REPENNING, C.A., BROUWERS, E.M., CARTER, L.D., MARINCOVICH, L., Jr., and AGER, T.A. 1987. The Beringian ancestry of $P h e-$ nacomys (Rodentia:Cricetidae) and the beginning of the modern Arctic Ocean biota. U.S. Geological Survey Bulletin 1687. 35 p.

ROGERS, K.L., REPENNING, C.A., FORESTER, R.M., LARSON, E.E., HALL, S.A., SMITH, G.S., ANDERSON, E., and BROWN, T.J. 1985. Middle Pleistocene (Late Irvingtonian) climatic changes in south-central Colorado. National Geographic Research 1:535-563.

RUDDIMAN, W.F., and RAYMO, M.E. 1988. Northern Hemisphere climate regimes during the past $3 \mathrm{Ma}$ : possible tectonic connections. Royal Society London, Philosophical Transactions, B318:411-430.

SHACKLETON, N.J., BACKMAN, J., ZIMMERMAN, H., KENT, D.V., HALL, M.A., ROBERTS, D.G., SCHNITKER, D., and BALDAUF, J. 1984. Oxygen isotope calibration of the onset of ice-rafting and history of glaciation in the North Atlantic region. Nature 307:620-623.

SHER, A.V., KAPLINA, T.N., KOUZNETSOV, Yu.V., VIRINA, E.I., and ZAZHIGIN, V.S. 1979. Late Cenozoic of the Kolyma Lowland. XIV Pacific Science Congress, Tour Guide XI. Moscow: Academy of Sciences of the U.S.S.R. 115 p.

TCHERNOV, E. 1979. Quaternary fauna. In: Horowitz, A., ed. The Quaternary of Israel. New York: Academic Press. 257-290.

ZAGWIJN, W.H., and DE JONG, J. 1984. Die Interglaziale von Bavel und Leerdam und ihre stratigraphische Stellung im niederlandischen fruhPleistozan. Rijks Geologische Dienst, Mededelingen 37-3:155-169.

ZAKRZEWSKI, R.J. 1972. Fossil microtines from late Cenozoic deposits in the Anza-Borrego Desert, California, with a description of a new subgenus of Synaptomys. Los Angeles County Museum of Natural History Contributions in Science 221:1-12.

ZHENG, S., and LI, C. In press. Comments on fossil Arvicolids of China. In: Fejfar, O., and Heinrich, W.-D., eds. International Meeting: Evolution, phylogeny, and biostratigraphy of Arvicolids (Rodentia, Mammalia) in Rohanov, Czechoslovakia. Prague: Geological Survey of Czechoslovakia. 